\title{
XLIV. An account of some experiments on the flexibility and strength of stones
}

\section{Mr. Thomas Tredgold}

To cite this article: Mr. Thomas Tredgold (1820) XLIV. An account of some experiments on the flexibility and strength of stones, Philosophical Magazine Series 1, 56:270, 290-295, DOI: 10.1080/14786442008652407

To link to this article: http://dx.doi.org/10.1080/14786442008652407

册 Published online: 23 Jul 2009.

Submit your article to this journal

Џ Article views: 2

Q View related articles $\asymp$ 
the author of the English formula is wrong in stating that it wil give the value of the correction with perfect accuracy; and the Commissioners of Longitude ought not to have sanctioned such an assertion. In the present state of astronomy, and when a new impulse seems to be given to the science, every one must hail with satisfaction any attempt to expedite and facilitate the laborious calculations which too frequently arise in practice : and no one is more sensible than I am of the ability and disposition of the members of the Board to encourage such attempts. Let us not however retrograde in the science, but endeavour to improve on what has gone before: so that we may eventually hope to regain that proud pre-eminence from which we have been driven by our more industrious neighbours.

I am, sir, your obedient servant,

Philaster.

XLIV. An Account of some Experiments on the Flexibility and Strength of Stones. By Mr. Thomas Tredgold.

To Mr. Tilloch.

SIR, - IN these experiments the piece under trial was supported at each end upon iron supports; the scale for the weights was suspended from the middle between these supports; and a silken line, attached to the middle, moved a lever index; which multiplied the depression so as to render a very small quantity visible.

The scale and its apparatus weigh ten pounds; and the weights I use are cubical pieces of iron, cast for the purpose, of 10 lbs. each. Weights of this kind pack neatly together upon the scale, and there is less risk of error in counting them than common weights.

The weight in the scale was increased by $10 \mathrm{lbs}$, at a time, laid on as softly as possible, and the index was always allowed to become stationary before another addition was made to the weight. The time which elapsed before the index became stationary was not observed, but it always increased sensibly towards the end of the experiment. I had the advantage of my brother's assistance in making the experiments where the fexure was measured.

\section{Detail of Experiments.}

1. A piece of white statuary marble, of a very regular texture, free from veins, or other apparent defects, was tried at three different lengths; the short specimens were the fragments of the long one. The piece was not perfectly uniform in breadth and depth, but the dimensions at the places of fracture are given.

Distance 


\begin{tabular}{|c|c|c|c|c|c|}
\hline $\begin{array}{l}\text { Distance be- } \\
\text { tween the } \\
\text { Supports } \\
\text { Depth. } \\
\text { Breadth. }\end{array}$ & $\begin{array}{l}\int_{30 \text { Inches. }} \\
.1 \cdot 075- \\
.1 \cdot 075-\end{array}$ & $\begin{array}{l}\text { Distance b } \\
\text { tween th } \\
\text { Support } \\
\text { Depth } \\
\text { Breadth }\end{array}$ & $.1 .08=$ & $\begin{array}{l}\text { Distance be } \\
\text { tween th } \\
\text { Supports } \\
\text { Depth } \\
\text { Breadth }\end{array}$ & 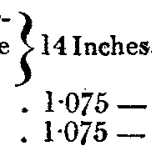 \\
\hline $\begin{array}{l}\text { Weight. } \\
10 \text { lbs. } \\
20- \\
30- \\
40- \\
50-\end{array}$ & $\begin{array}{l}\text { Depression. } \\
.02 \text { inch. } \\
.045- \\
.06- \\
.08- \\
\text { Broke - }\end{array}$ & $\begin{array}{c}\text { Weight. } \\
10 \mathrm{lbs} . \\
20- \\
30- \\
40- \\
50- \\
60- \\
70- \\
80- \\
90- \\
100- \\
110-\end{array}$ & $\begin{array}{c}\text { Depression. } \\
.005 \text { inch. } \\
.01- \\
.012- \\
.015- \\
.017- \\
.02- \\
.021- \\
.025- \\
.03- \\
.035- \\
\text { Broke. }\end{array}$ & $\begin{array}{l}\text { Weight. } \\
10 \mathrm{lbs} . \\
20- \\
30- \\
40- \\
60- \\
70- \\
90- \\
100- \\
110- \\
120- \\
130-\end{array}$ & $\begin{array}{l}\text { Depression. } \\
\text { not sensible } \\
.005 \text { inch. } \\
.01- \\
.012- \\
.015- \\
.02- \\
.025- \\
.027- \\
.03- \\
.034- \\
.037 \text { and } \\
\text { coke. }\end{array}$ \\
\hline
\end{tabular}

The first trial, that with the 30-inch distance, will give the most accurate measure of the elastic force; but it is not a fair measure of the cohesive force, because it was evidently broke by the momentum, the weight acquired by the addition of the last $10 \mathrm{lbs}$. The 14-inch length bore the weight some time before it broke.

The specific gravity was found to be 2.706 ; and it absorbs $\frac{1}{305}$ of its weight of water.

I observed that the fractures bore a close resemblance to one another, and found that the plane of fracture made always nearly the same angle with the axis of the piece. 'This angle is about $83^{\circ}$. I have not observed a similar regularity in any other kind of stone, and it is either a remarkable coincidence, or the effect of the structure of this kind.

2. There is some difference in the quality of the Portland stone used in London; the best and strongest kind is of a browner colour than the others. The specimen with which our experiment was made was of the brown variety, and of a regular texture, without apparent defect. The length between the supports was 24 inches, the breadth 2 inch, and the depth $1 \cdot 4.5$ inch.

$$
\begin{aligned}
& \text { Weight } 10 \text { lbs. .. Depression } 01 \text { inch. }
\end{aligned}
$$

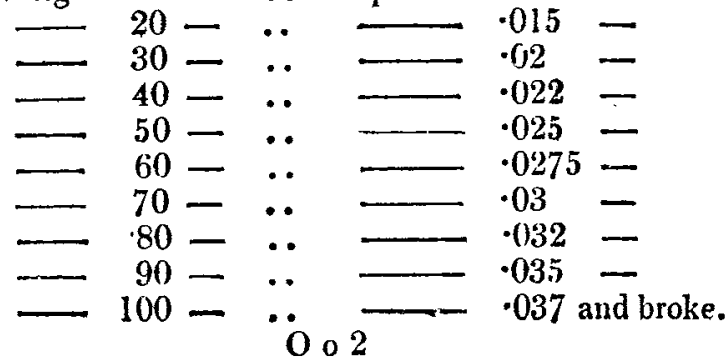


This was a very good experiment, as we knew from previous trials very nearly the weight it would bear, and therefore added the weights with more care towards the last.

The specific gravity of the specimen was found to be $2 \cdot 113$, and it absorbs $\frac{1}{16}$ of its weight of water.

3. Our next trial was made with a piece of white siliceous sandatone from Lord Keith's quarries at Long-annet, near Kincardine Tuilyallan, on the north side of the Forth. The specific gravity of this stone is $2 \cdot 212$, and it absorbs $\frac{1}{6}$, of its weight of water. The texture regular, with small scales of mica distributed through it. The distance between the supports was 18 inches, the breadth 1.45 inch., and the depth 1.525 inch.

$$
\begin{aligned}
& \text { Weight 20lbs. ... Depression } .015 \text { inch. }
\end{aligned}
$$

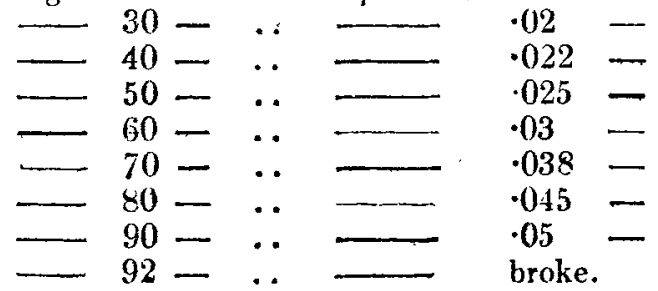

This stone is of a more flexible nature than either of the preceding; though from its appearance I expected a different result.

4. The following table contains the results of some experiments in which the flexure was not ascertained; they were made for olvtaining data for calculating the lateral strength of stone.

These specimens, with the exception of one of the Longannet onos, were laid with their natural beds horizontally.

Talle of Experiments on the lateral Strength of Stones.

\begin{tabular}{|c|c|c|c|c|c|}
\hline Kind of Stone. & $\begin{array}{l}\text { Distance be- } \\
\text { tween the } \\
\text { Supports. }\end{array}$ & $\begin{array}{l}\text { Breadth. } \\
\text { Inches. }\end{array}$ & $\begin{array}{l}\text { Depth. } \\
\text { Inch. }\end{array}$ & $\begin{array}{l}\text { Weight that } \\
\text { broke the } \\
\text { Piece. }\end{array}$ & $\begin{array}{l}\text { Weight of a } \\
\text { cubic Foot. }\end{array}$ \\
\hline Dundee stone & 14 inches. & $1 \cdot 45$ & $1 \cdot 5$ & 414 lbs, & $163.8 \mathrm{lbs}$. \\
\hline $\left.\begin{array}{c}\text { Craigleith } \\
\text { stone }\end{array}\right\}$ & $14-$ & 1.55 & $1 \cdot 55$ & $137-$ & $147 \cdot 6-$ \\
\hline Hailes stone & $14-$ & 1.55 & 1.5 & $123-$ & $134.8-$ \\
\hline $\begin{array}{l}\text { Long-annet } \\
\text { stone .. }\end{array}$ & $9-$ & 1.525 & 1.45 & $160-$ & $138 \cdot 25-$ \\
\hline $\left.\begin{array}{c}\text { Do.another } \\
\text { specimen }\end{array}\right\}$ & $7-$ & 1.55 & 1.55 & $233-$ & \\
\hline $\begin{array}{l}\text { Portland stone } \\
\text { Bath stone. }\end{array}$ & $125-$ & $\begin{array}{l}2.07 \\
1.0\end{array}$ & $\begin{array}{l}1 \cdot 55 \\
1 \cdot 0\end{array}$ & $\begin{array}{r}270- \\
58-\end{array}$ & $\begin{array}{l}132= \\
123.4-\end{array}$ \\
\hline
\end{tabular}

The 
The Dundee stone is from the Mylne-field quarry, near Dundee; the specimen tried is superior to the kind usually raised from that quarry both in fineness of texture and density. Its specific gravity is 2.621 , and it absorbs only ${ }_{3}^{1} \mathrm{~T}$ of its weight of water.

The Craigleith stone is a fine specimen from the quarries of that name near Edinburgh. Specific gravity 2.362, and absorbs $\frac{1}{63}$ of its weight of water.

The Hailes quarry stone is also from near Edinburgh, and from the same stratum as the Craigleith, but differs from it in being more laminated."

Long-annet stone is also about of the same kind as Craigleith; the 7 -inch length was a variety of a coarser texture; the other was a fragment of the piece of which the flexure was measued.

The specinens of Bath and Portland stone were good of their respective kinds, and such as are usually employed about London.

5. In order to compare the results of these experiments, I will use the following formulx; in which $w$ is the weight that produces a deflexion $\delta$; and $W$ the weight that broke the piece; $\Delta$ being the depression at the time of fracture; $l=$ half the length; $b=$ the breadth; and $d=$ the depth.

$\frac{23^{3} v}{d d^{3} \delta}=$ The weight of the modulus of elasticity, or measure of the elastic force*.

$\frac{3 d \Delta}{2 l^{2}}=$ The extension at the time of fracture.

$\frac{3}{b} \frac{\mathrm{W}}{d^{2}}=$ The cohesive force of the material, on the supposition that the resistance to tension is equal to the resistance to compression.

As the elastic force of a substance appears to decrease when the strain much exceeds about half the cohesive force, in calculating the elastic force the weight $w$ will be taken, which is nearest to half the weight that broke the piece.

The hardness was compared by scratehing a piece of each stone with the same piece of steel, applied in the same manner, and, as nearly as 1 could judge, with the same force. I had not an apparatus fit for the purpose, or I would have used Perronet's nethod of determining the hardness. The last column of the table shows the order of hardness, making the softest 1 .

* Dr. Young's Nat. Phil. vol. ii. art. 326. 
Table of the Properties of some Species of Stone.

\begin{tabular}{|c|c|c|c|c|c|c|c|}
\hline Kind of Stone. & $\begin{array}{c}\text { Cohesive } \\
\text { Force of a } \\
\text { square } \\
\text { Inch. }\end{array}$ & $\begin{array}{l}\text { Weight of } \\
\text { the Modulus } \\
\text { of Elasticity } \\
\text { of a square } \\
\text { Inch. }\end{array}$ & $\begin{array}{l}\text { Height of } \\
\text { the Modu- } \\
\text { lus of } \\
\text { Elasticity } \\
\text { in Feet. }\end{array}$ & 咅离 & 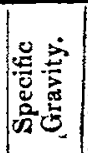 & 迸 & \\
\hline $\begin{array}{l}\text { Statuary } \\
\text { marble }\end{array}$ & $\mid \begin{array}{l}1,811 \text { lbs. } \\
2,020- \\
2,197-\end{array}$ & $\begin{array}{l}2,513,000 \mathrm{lbs} . \\
1,910,000- \\
1,800,000-\end{array}$ & $\left|\begin{array}{l}2,109,000 \\
1,591,000 \\
1,500,000\end{array}\right|$ & & $2 \cdot 706$ & $\frac{1}{300}$ & \\
\hline $\begin{array}{c}\text { Portland } \\
\text { stone } . .\end{array}$ & $\mid \begin{array}{l}857- \\
976-\end{array}$ & $\begin{array}{c}1,152,000- \\
. .\end{array}$ & $\left|\begin{array}{c}1,256,000 \\
.\end{array}\right|$ & $\begin{array}{l}\frac{1}{789} \\
. \quad .\end{array}$ & $\left|\begin{array}{c}2 \cdot 113 \\
\cdot .\end{array}\right|$ & $\left.\frac{1}{16}\right\}$ & \\
\hline $\begin{array}{r}\text { Long-annet } \\
\text { stone } .\end{array}$ & $\begin{array}{l}734- \\
675- \\
656-\end{array}$ & $\begin{array}{l}569,000- \\
. \quad . \quad . \\
. \quad . \quad\end{array}$ & $\begin{array}{c}593,000 \\
\cdot . \\
\cdot \\
\cdot\end{array}$ & $\begin{array}{l}\frac{1}{708} \\
\cdot . \\
\cdot .\end{array}$ & $\cdot$. & $\frac{1}{6} \cdot 7$ & \\
\hline Dundee stone & $2,661-$ & $\cdot \cdot \cdot \cdot$ & $\cdot \cdot \cdot$ & & $2 \cdot 621$ & $\frac{1}{51}$ & \\
\hline eith .7 & $772-$ & . . . . & . . & . . & $2 \cdot 362$ & $\frac{1}{83}$ & \\
\hline arry & $740-$ & . . . & $\cdot \cdot \cdot$ & . & $2 \cdot 155$ & $\cdot \cdot$ & 5 \\
\hline Bath stone & $478-$ & . . . & $\cdot \cdot \cdot$ & $\cdot$. & $1.975 \mid$ & & \\
\hline
\end{tabular}

In theory it is considered that bodies are perfectly homogeneous; but in our trials we found that the magnitude of the facet of a crystal, or the position of a scale of mica, produeed a sensible effect on the result in a small specimen : therefore, to determine the strength, the specimer should not exceed about 18 inches in length, with a section of an inch and half square. When a specimen is long, it is not easy to add to the weight without giving it a sensible degree of momentum. To determine the elastic force, the specimen should be long in proportion, to its depth, and it is better when the breadth is not less, than twice the depth; then both the flexure, and the weight producing it, being greater, the elastic force will be more correctly obtained. In short specimens there is a sensible degree of indentation at the supported ends.

I have observed, that of late stone-stairs, balconies, landings, \&ic. are executed with a less and less quantity of material, and that there is no prospect of a stop being put to this species of misplaced oconomy till some dreadful accident happens. What a scene of horror the failure of a crowded balcony would create ! and who can say what balcony may not be loaded to the utmost 
the space will allow of? They should be calculated to bear the greatest possible load, with safety. My experiments furnish the necessary data as far as regards the strength of the stone. They also show which stone is best adapted for the purpose. The Dundee stone is decidedly the strongest of the specimens I have tried.

Oct. 17, 1820.

I am, sir, yours, \&c.

2, Grove Terrace, Lisson Grove.

Thomas Trengold.

XLV. Analysis of Arsenical Nickel, and the Arseniate of Nickel of Allemont (Department of the Isere). By M.BerTHIER*.

$\mathrm{T}$ $\mathrm{T}_{\mathrm{H} \text { E }}$ arsenical nickel of Allemont has not hitherto been completely analysed. Its colour is reddish brown, approaching that of copper, but paler; it has a metallic lustre both in pieces and in powder ; its fracture even, or covered with small asperities, and a little shining; it soon tarnishes in the alr ; it is brittle, and easily reduced to powder:- specific gravity $7 \cdot 29$. It emits a garlic smell when struck with steel; before the blow-pipe it gives a dense arsenical smoke; melts readily a little above a red heat. Heated for an hour at $150^{\circ}$ of Wedgwood, in a crucible lined with charcoal, it loses only about $0 \cdot 12$ to 0.15 of its weight, and does not change its appearance. This loss appears to be almost entirely arsenic.

This mineral consists principally of arsenieuret of nickel, but contains also a small quantity of arsenieuret of cobalt and sulphuret of antimony. It was analysed in the manner following:

To the mineral was added nitric aeid at intervals; and it was boiler during two days, which dissolved the whole. The arsenic and sulphur were acidified, and the nickel, cobalt and antimony oxidated. Water being added to the solution, a white powder fell down, weighing when dry 0.276 parts, which was proved to consist almost entirely of arseniate of antimony, by the following experiments : It was first heated in a silver crucible, with four times its weight of caustic potash; and then treated with boiling water, which dissolved all but a small residue of oxide of nickel, weighing 0.008 , arising from a small portion of arseniate of nickel which had fallen down along with the arseniate of antimony. The above-mentioned solution in boiling water was then boiled with nitric acid, which produced a white sediment, composed of oxide of antimony and arsenic acid, weighing $0 \cdot 16$ parts: Its component parts were separated by solution in muriatic acid, slow evaporation to dryness, and subsequent addition of water, which caused a copious deposit of in-

* From the Journ. des Mines, iv. 467. 